\title{
Cadmium, Iron and Chromium Removal from Simulated Waste Water Using Algae, Water Hyacinth and Water Lettuce
}

\author{
Sani Nasiru Alhaji ${ }^{1, ~ *, ~ S u l a i m a n ~ A s m a u ~ U m a r ~}{ }^{2,3}$, Sokoto Abdullahi Muhammad ${ }^{3}$, Shehu Kasimu ${ }^{4}$, \\ Salisu Aliyu ${ }^{1}$ \\ ${ }^{1}$ Department of Chemistry, Federal University, Gusau, Nigeria \\ ${ }^{2}$ Department of Chemistry, Shehu Shagari College of Education, Sokoto, Nigeria \\ ${ }^{3}$ Department of Pure and Applied Chemistry, Usmanu Danfodiyo University, Sokoto, Nigeria \\ ${ }^{4}$ Department of Biological Sciences, Usmanu Danfodiyo University, Sokoto, Nigeria
}

Email address:

nasirualhajisani@yahoo.com (S. N. Alhaji)

${ }^{*}$ Corresponding author

\section{To cite this article:}

Sani Nasiru Alhaji, Sulaiman Asmau Umar, Sokoto Abdullahi Muhammad, Shehu Kasimu, Salisu Aliyu. Cadmium, Iron and Chromium Removal from Simulated Waste Water Using Algae, Water Hyacinth and Water Lettuce. American Journal of Applied Chemistry.

Vol. 9, No. 1, 2021, pp. 36-42. doi: 10.11648/j.ajac.20210901.15

Received: January 5, 2021; Accepted: January 13, 2021; Published: January 30, 2021

\begin{abstract}
Phytoremediation involves the use of some aquatic plants for soil and water cleanup. It involves the use of hyperaccumulator plant species that remove metals from contaminated environment. In the present study, the effectiveness of Algae, Water hyacinth and Water lettuce for the removal of $\mathrm{Cd}, \mathrm{Fe}$, and $\mathrm{Cr}$ from simulated wastewater was tested. The three aquatic plants were grown in aqueous medium and supplemented with $1.0,3.0$ and $5.0 \mathrm{mg} / 1$ of multi-component metal solution for 15 consecutive days. The experiment showed that the plants were able to accumulate the metals at all concentrations. The respective concentration $(\mathrm{mg} / \mathrm{kg})$ ranges of the metals $(\mathrm{Cd}, \mathrm{Fe} \& \mathrm{Cr})$ are: in Algae; 37.38-268.74, 3.10-80.80, 66.78-671.20; water hycinth: 16.59-277.20, 0.56-235.32, 3.12-1661.94; water lettuce: 38.58-208, 0.35-538, 6.05-283.84. The accumulation of metals increased significantly, with increase in the initial concentration of the solution. At all levels, the plants accumulated the metals more in the root than in the shoot, except for $\mathrm{Fe}$ in water hyacinth which shows effective translocation from root to shoot. The result also showed that water hyacinth was able to concentrate $\mathrm{Cd}$ and $\mathrm{Cr}$ better than $\mathrm{Fe}$, while water lettuce concentrated $\mathrm{Fe}$ better. All the plants can be used in remediating wastewater, with water hyacinth revealing the best potentiality.
\end{abstract}

Keywords: Phytoremediation, Heavy Metals, Algae, Water Hyacinth, Water Lettuce

\section{Introduction}

Environmental pollution is one of the severe problems across the globe, the cause of which can be traced back to anthropogenic activities such as ore mining and crude oil exploration. The pollutants when accumulated, may have adverse effects on living organisms, causing gradual degradation of ecosystem [1]. Contamination of soil and the aquatic environment by heavy metals is one of the major threats to the water resources of the world today, mainly due to their non-degradability nature which is hazardous when discharged into a water body [2]. Moreover, heavy metals also posed a great threat to human health which can lead to different health abnormalities; high blood pressure, kidney damage, sterility in males, cancer, among others [3].

Devastation caused by heavy metal pollution has led to the emergence of different conventional methods (reverse osmosis, ion exchange, chemical precipitation, and electro dialysis) for averting their environmental effects [1\&4]. These so called conventional methods are quite costly, energy intensive and metal specific. On the other hand, biotic remediation (most notably Rhizofiltration process) offers a promising technology and cost effective method for heavy 
metal removal from waste water [5].

Recently, there has been a growing interest in using algae for biomonitoring eutrophication of organic and inorganic pollutants [6-7]. Algae have been implored in waste water treatment mainly, due to its heavy metal cations, based on high negative surface charge. This is an advantage from the view-point of tertiary sewage treatment, but a disadvantage if the intent is to use waste-grown algae for fish or livestock feeding [8]. Benchraka (2014) reported the use of ten algal spp in Algae Turf Scrubber (ATS) for a period of 21 days for the removal of $\mathrm{Zn}$ and $\mathrm{Ni}$, with $99 \%$ removal efficiency for $\mathrm{Zn}$ [9]. Giovanni et al., (2012) also reported the use of five Rppalustis strains (an algal species) to explore the metal removal capacity for $\mathrm{Ru}$ [10]. The use of Synechocystis Salina (an algal sp) by Worku and Sahu, (2014) has also led to a successful removal of $\mathrm{Cr}, \mathrm{Fe}, \mathrm{Ni}$, and $\mathrm{Hg}$ in 15 days, with a very good efficiency [11].

Water hyacinth (E. crassipes) is another aquatic plant reported to have shown a very good bioremediation potentiality [12]. It is the most common specie of the genus Eichhornia. The properties that qualify it for use in wastewater treatment includes; its enormous biomass production rate, high tolerance to pollution, good absorption capacity of heavy metal and nutrient [13, 14]. A comprehensive study on arsenic removal from water by $E$. crassipes was performed by Alvarado et al., 2008, and the results revealed that it can remove up to $600 \mathrm{mg}$ of arsenic, out of which $18 \%$ can be recovered under laboratory conditions. The removal efficiency of water hyacinth was due to its high biomass production and favourable climatic conditions [15]. Water hyacinth (E. crassipes) represents also a reliable alternative for arsenic bioremediation in aquatic system even though the plant may cause severe water management problems, mainly due to its huge vegetative reproduction and high growth rate [16].

Swain et al., (2014) also reported the use of water hyacinth (E. crassipes) for the removal of copper $(\mathrm{Cu})$ and cadmium (Cd) with removal efficiency of over $90 \%$, judging from the result water hyacinth is a very good accumulator of $\mathrm{Cu}$ with higher bioconcentration factor than that of $\mathrm{Cd}$ and a moderate accumulator of Cd [17]. Narain et al. (2011) has also given an overview of using water hyacinth (E. crassipes) for $\mathrm{Cd}$ and $\mathrm{Cr}$ removal with a very good efficiency $(80.26 \%$ for $\mathrm{Cr}$ and $71.28 \%$ for Cd) [18].

Although Water lettuce (P. stratiotes) mats degrade water quality by blocking the air-water interface, which reduces the oxygen levels in the water, and threaten the aquatic life, it has been tested for metal remediation, metal detoxification, and treatment of urban sewage [19, 20, 21 \& 22]. Espinosa, (2001) cultured $P$. Stratiotes in solutions amended with three different lead levels (2ppm, 4ppm and 8ppm) and reported that $P$. Stratiotesmight be useful in metal decontamination process in industrial and domestic wastewaters [23]. Thilakaret al., (2012) compared the use of Pistiastratiotes and Salvinianatansin remediating heavy metals $(\mathrm{Cr}$ and $\mathrm{Cu})$ for a period of 10 days in a shaded area in a single metal solution of $25 \%, 50 \%, 75 \%$ and $100 \%$ concentrations of $\mathrm{Cr}$ and $\mathrm{Cu}$ respectively [24]. The results revealed that both plants are efficient accumulators of these metals hence, can be effectively use to clean up aquatic ecosystem. Its potentiality for the removal of $\mathrm{Zn}, \mathrm{Co}, \mathrm{Hg}, \mathrm{Cd}, \mathrm{Mn}, \mathrm{Ag}$, and $\mathrm{Pb}$ in a polluted stream were also reported [5, $26 \& 27]$.

The present work aimed to ascertain the bioaccumulative ability of algae, water hyacinth and water lettuce for $\mathrm{Cr}, \mathrm{Cd}$ and $\mathrm{Fe}$ removal in a multi component metal solution. The focus of this work is only on quantification of the metal uptake by plants under investigation. This research work will therefore not cover handling of waste biomass after the experiment.

\section{Experimental}

\subsection{Sampling}

The three aquatic plants [alga (Spirogyrasp.), water hyacinth (EichhorniaCrassipes), and water lettuce (Pistiastratiotes)] were obtained from Sokoto metropolis, $\left(13.0059^{\circ} \mathrm{N}, 5.2476^{\circ} \mathrm{E}\right)$ and authenticated by a curator in the Department of Biological Sciences, Usmanu Danfodiyo University, Sokoto. The plant materials were then washed, collected in a clean plastic container and kept in biological sciences botanical garden for a period of one week to acclimatize to the environmental conditions of the garden [17].

\subsection{Experimental Set $U p$}

Exactly $15 \mathrm{dm}^{3}$ containers were used in conducting the experiment for all the samples. Metal $(\mathrm{Cd}, \mathrm{Cr}$ and $\mathrm{Pb})$ solutions of three different concentrations $(1,3$, and $5 \mathrm{mg} / \mathrm{l})$ were prepared, followed by addition of nutrient in the form of Hoagland solution. The Fourth solution (the control) contained only Hoagland solution, and the $\mathrm{pH}$ of each solution was adjusted to 6 using acetic acid [12].

Different concentrations of the metal solutions were administered to the containers containing the plant materials. The weight of the plant materials was taken before and after administering the heavy metal solution. From each container, $50 \mathrm{~cm}^{3}$ of water sample was collected after $24 \mathrm{hrs}, 5$ days, 10 days and 15 days of the metal administration. 5 drops of $\mathrm{HNO}_{3}$ acid was added to each of the collected sample (for proper storage) before AAS analyses [12].

The experiment was conducted for a period of 15 days in a shady area according to the technique reported by Banach et al., (2012)[1]. At the end of the $15^{\text {th }}$ day the plants were harvested, washed and then separated into roots and shoot which were then analysed for metal accumulation using standard techniques.

\subsection{Determination of Heavy Metals}

\subsubsection{Sample Treatment}

The plants samples were harvested on the $15^{\text {th }}$ day and washed with distilled water to remove any adhered substance, it was then separated into shoot and root and then allowed to dry, and the air dried sample was grinded and 
sieved.

\subsubsection{Digestion}

The ashing procedure was done in order to prepare plant samples for elemental analysis. This was done using dry ashing method [27].

\subsubsection{Wet Digestion}

Air dried sample $(1.00 \mathrm{~g})$ was placed in a beaker, followed by the addition of $\mathrm{HNO}_{3}\left(10 \mathrm{~cm}^{3}, 6 \mathrm{M}\right)$ and $\mathrm{HClO}_{4}\left(2 \mathrm{~cm}^{3}\right)$. The beakers were covered with a watch glass for an hour, heated on a hot plate at $90^{\circ} \mathrm{C}$ for 30 mins, filtered and transferred into $50 \mathrm{~cm}^{3}$ volumetric flask with washing [27].

\subsubsection{AAS Analysis}

The alpha 4 model of Atomic Absorption Spectrophotometer was calibrated using standard solution prepared from stock solution in accordance with the manufacturer's instructions with the wavelength corresponding to that of the metals $(\mathrm{Cr}, \mathrm{Cd}, \mathrm{Fe})$ under investigation. The absorbance of each sample was measured in triplicate with an automatic calculation of the average concentration in parts per million (ppm).

\subsubsection{Statistical Analysis}

The analysis was carried out on three independent replicates for every parameter. The results presented in Table 1 are reported as mean \pm standard deviation (SD). Data were subjected to normality test and subsequently analysed using SSPS Anova two ways considering significance at an alpha level of 0.05 .

\section{Results}

The result of heavy metal analysis in different parts of plants under investigation in a multi component metal solution is summarised in Table 1 and represented in Figures 1 to 3. The bioconcentration factor, transfer factor Tables 2 and 3. Absorption trend/properties of metal under investigation is given in Table 4.

Table 1. Bioaccumulation of Heavy Metal by Different Plant Materials.

\begin{tabular}{|c|c|c|c|c|}
\hline \multirow{2}{*}{ Plant (mg/kg) } & \multirow{2}{*}{ Concentration $\left(\mathrm{mg} / \mathrm{dm}^{3}\right)$} & \multicolumn{3}{|l|}{ Heavy Metal } \\
\hline & & Cd & $\mathbf{F e}$ & $\mathrm{Cr}$ \\
\hline Algae (control) & & ND & $910.13 \pm 0.02$ & $94.64 \pm 0.02$ \\
\hline \multirow{2}{*}{ W. H (control) } & Shoot & ND & $136.7 \pm 0.01$ & $88.06 \pm 0.02$ \\
\hline & Root & ND & $996.47 \pm 0.01$ & $138.58 \pm 0.02$ \\
\hline \multirow{2}{*}{ W. L. (control) } & Shoot & ND & $6.903 \pm 0.93$ & $3.51 \pm 0.62$ \\
\hline & Root & ND & $0.17 \pm 0.02$ & $0.27 \pm 0.1$ \\
\hline \multirow{2}{*}{ Algae } & 1 & $37.38 \pm 0.99$ & $3.10 .23 \pm 0.1$ & $66.78 \pm 0.02$ \\
\hline & 5 & $268.74 \pm 2.86^{\mathrm{b}}$ & $80.80 \pm 0.84$ & $671.28 \pm 0.02^{\mathrm{c}}$ \\
\hline \multirow{3}{*}{ W. H Shoot } & 1 & $16.59 \pm 0.01$ & $27.53 \pm 1.84$ & $3.12 \pm 0.02$ \\
\hline & 3 & $34.32 \pm 5.72$ & $222.73 \pm 0.64^{d}$ & $23.53 \pm 0.02$ \\
\hline & 5 & $65.24 \pm 5.24$ & $235.32 \pm 14.24^{\mathrm{e}}$ & $27.69 \pm 1.82$ \\
\hline \multirow{3}{*}{ W. H Root } & 1 & $255.26 \pm 6.05^{\mathrm{d}}$ & $0.56 \pm 0.08$ & $261.59 \pm 0.01^{\mathrm{d}}$ \\
\hline & 3 & $262.09 \pm 0.07^{\mathrm{c}}$ & $3.42 \pm 0.38$ & $1139.80 \pm 0.2^{\mathrm{b}}$ \\
\hline & 5 & $277.20 \pm 0.1^{\mathrm{a}}$ & $27.53 \pm 1.55$ & $1661.94 \pm 0.02^{\mathrm{a}}$ \\
\hline \multirow{2}{*}{ W. L Shoot } & 1 & $38.58 \pm 0.02$ & $0.35 \pm 0.06$ & $6.05 \pm 0.01$ \\
\hline & 5 & $86.93 \pm 0.02$ & $26.41 \pm 13.56$ & $61.60 \pm 0.2$ \\
\hline \multirow{3}{*}{ W. L Root } & 1 & $97.21 \pm 0.01$ & $312.60 \pm 0.2^{\mathrm{c}}$ & $130.20 \pm 0.2$ \\
\hline & 3 & $129.30 \pm 0.02$ & $438.06 \pm 0.02^{\mathrm{b}}$ & $227.60 \pm 0.1$ \\
\hline & 5 & $208.10 \pm 6.55^{\mathrm{e}}$ & $538.59 \pm 0.02^{\mathrm{a}}$ & $283.84 \pm 0.01^{\mathrm{e}}$ \\
\hline
\end{tabular}

1. Results are expressed as mean $\pm \mathrm{SD}$.

2. Values with superscript ${ }^{(\mathrm{a}-\mathrm{e})}$ are the first five best bioaccumulating plant/plant part at alpha 0.05 .

3. W.H= water hyancith, W.L = Water lettuce

\subsection{Cadmium Concentration}

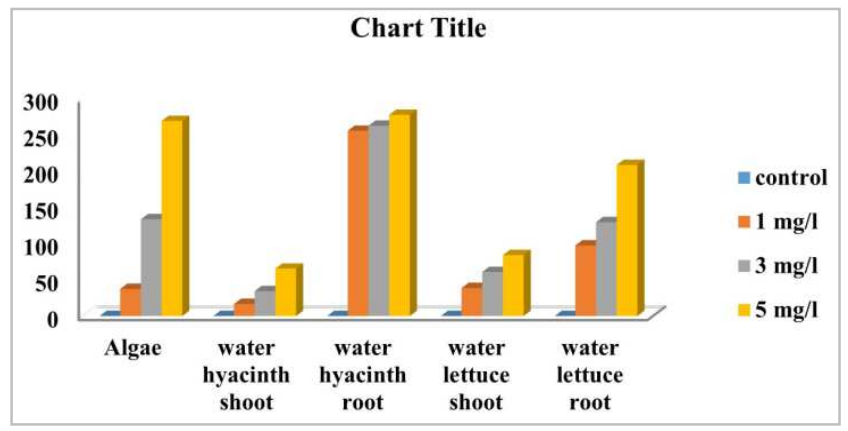

Figure 1. Cadmium concentration in different plant samples.
Figure 1 illustrates the trend of $\mathrm{Cd}$ concentration in the plant samples. The Figure showed the presence of $\mathrm{Cd}$ in all the plant samples. In all the plants materials the $\mathrm{Cd}$ concentration tend to increase with an increase in the concentration of the multi metals solution $(5 \mathrm{mg} / \mathrm{l}>3 \mathrm{mg} / \mathrm{l}>1$ $\mathrm{mg} / \mathrm{l})$. Algae and water hyacinth root at $5 \mathrm{mg} / \mathrm{l}$ showed the highest accumulation of $\mathrm{Cd}$.

\subsection{Iron Concentration}

Figure 2 gives the concentration of Iron in various parts of plants under investigation. Like in the case of Cd (Figure 1) above, the trend of metal accumulation tends to increase with an increase in the concentration of the working solution. 
Additionally, significant amount of Fe was observed in the control solution of algae and water hyacinth root. However, Water lettuce root showed the best absorbing capacity for the metal when compared with the other plant/plant parts.

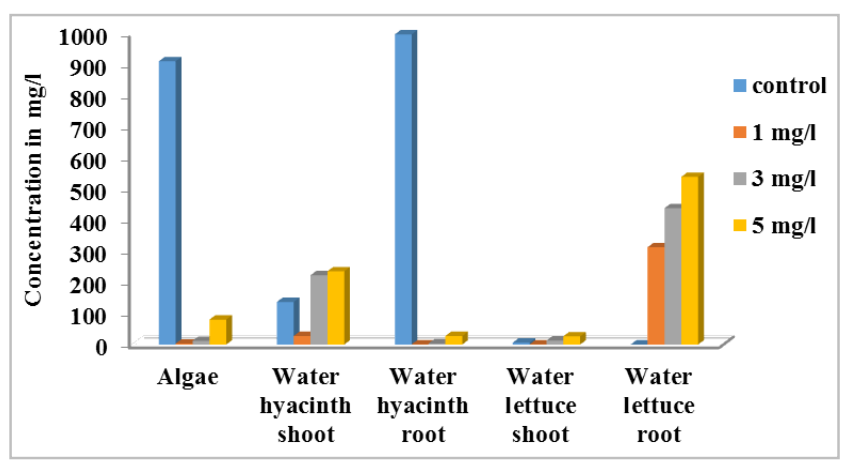

Figure 2. Iron concentration in different part of plant samples.

\subsection{Chromium Concentration}

Figure 3 Illustrates the $\mathrm{Cr}$ accumulation in different parts of plants under investigation. Highest accumulation of the metal at different concentrations was observed in water hyacinth root followed by algae and water lettuce root.

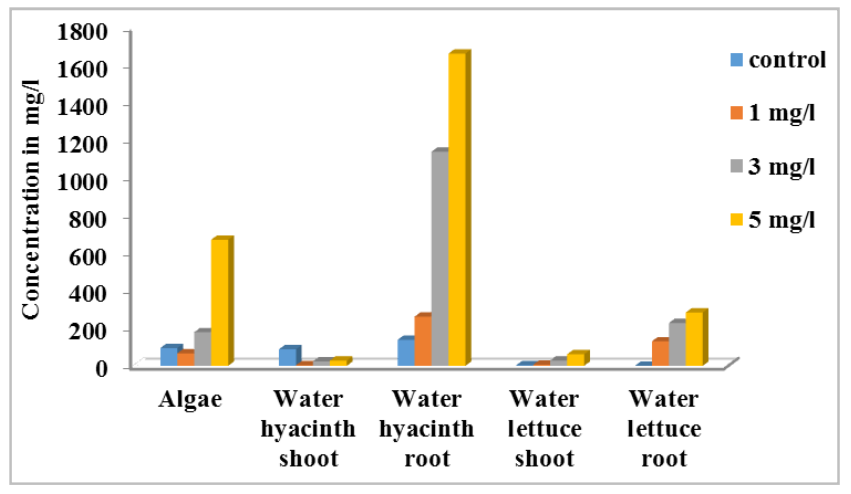

Figure 3. Chromium concentration in different plant samples.

Table 2. Bioconcentration factor of Algae, Water hyacinth and Water lettuce.

\begin{tabular}{lllll}
\hline \multirow{2}{*}{ Plant } & Concentration & \multicolumn{3}{c}{ Heavy metals (mg/kg) } \\
\cline { 3 - 5 } & $(\mathbf{m g} / \mathbf{l})$ & $\mathbf{C d}$ & $\mathbf{F e}$ & $\mathbf{C r}$ \\
\hline \multirow{3}{*}{ Algae } & 1 & 37.38 & 3.10 & 66.78 \\
& 3 & 44.45 & 3.73 & 59.63 \\
Water hyacinth shoot & 5 & 53.75 & 16.16 & 134.26 \\
& 1 & 16.59 & 27.53 & 3.12 \\
Water hyacinth root & 3 & 11.44 & 74.24 & 7.84 \\
& 5 & 13.05 & 47.06 & 5.54 \\
Water lettuce shoot & 3 & 255.26 & 0.56 & 261.59 \\
& 1 & 87.36 & 1.14 & 379.93 \\
& 5 & 55.44 & 5.51 & 332.39 \\
Water lettuce root & 3 & 38.58 & 0.35 & 6.05 \\
& 1 & 20.23 & 4.29 & 9.35 \\
& 5 & 17.39 & 5.28 & 12.32 \\
& 5 & 97.21 & 312.6 & 130.2 \\
\hline
\end{tabular}

Bioconcentration factor $=\mathrm{a} / \mathrm{b}$, where $\mathrm{a}=$ metal concentration in plant and $\mathrm{b}=$ metal concentration in water [25\&17].

\subsection{Bio-concentration Factor}

Bioconcentration factor is a useful parameter for assessing the potential of metal accumulation. When metal concentration in water increases, the amount of metal accumulated in plant increases thus the bioconcentration factor decreases. Bioconcentration factor also provides index of the ability of plant to accumulate metal with respect to the concentration of that metal in the substrate [17]. Results in Table 1 showed that water hyacinth was able to concentrate the $\mathrm{Cd}$ and $\mathrm{Cr}$ relative $\mathrm{Fe}$, while water lettuce was able to accumulate Fe better than $\mathrm{Cd}$ and $\mathrm{Cr}$. Larger value of the bio-concentration factor implies better accumulation capability [12].

\subsection{Transfer Factor}

The TF expresses the capacity of a plant to store the metals in its upper part. This is defined as the ratio of metal concentration in the upper part to that in the roots. In other words, Biotransfer factor shows the ability of the plant to transport metal ion in to the shoot tissues [12].

If $\mathrm{TF}>1$, it indicates that the plant translocate metals effectively from roots to the shoot [28]. Of the metals $(\mathrm{Cd}$, $\mathrm{Cr}, \mathrm{Fe}$ ) only $\mathrm{Fe}$ was effectively translocated. Water hyacinth was able to translocate $\mathrm{Fe}$ according to results in (Table 3).

Table 3. Transfer factor.

\begin{tabular}{lllll}
\hline \multirow{2}{*}{ Plant } & $\begin{array}{l}\text { Concentration } \\
(\mathbf{m g} / \mathbf{l})\end{array}$ & \multicolumn{3}{l}{ Heavy metals (mg/kg) } \\
\cline { 3 - 5 } & 1 & $\mathbf{C d}$ & $\mathbf{F e}$ & $\mathbf{C r}$ \\
\hline \multirow{3}{*}{ Water hyacinth } & 3 & 0.06 & 49.16 & 0.01 \\
& 5 & 0.13 & 65.13 & 0.02 \\
& 1 & 0.24 & 8.55 & 0.02 \\
Water lettuce & 3 & 0.40 & 0.001 & 0.05 \\
& 5 & 0.47 & 0.03 & 0.12 \\
& 5 & 0.42 & 0.05 & 0.22 \\
\hline
\end{tabular}

Transfer factor $=\mathrm{c} / \mathrm{d}$,

where $\mathrm{c}=$ metal concentration in shoot and

$\mathrm{d}=$ metal concentration in root [25\&35].

\subsection{Trends of Heavy Metal Accumulation}

The chemistry of metal is in the ability of the metal attracting the opposite end of water molecule, the cations with smaller atomic radius create a more intense electric field thereby penetrating more water ions (Irfan, 2015). There are several factors that influence the affinity of cations towards a given surface (in this case the plants), firstly the surface coverage will increase as a function of the cations (size of the cation) secondly the affinity for the exchange sites is enhanced as the oxidation state increases. Finally the higher the charge density of the hydrated cation the greater will be its affinity for the exchange site [29] charge density decreases down the periodic table and then across from left to right as the charge increases the size decreases, having a smaller ionic radius gives higher charge density.

\section{Discussion}

Cadmium concentration was found to be highest in algae 
and water hyacinth root with 268.74 and $255.26 \mathrm{mg} / \mathrm{kg}$ respectively (Table 1), when compared with the other parts of plants under investigation. These values are in good agreement with the previously values from Yasar et al., (2013) [30]. The bioconcentration values (Table 2) for algae and water hyacinth root further supported the facts that, these plants are good accumulators for Cd. Therefore this is an indication that algae and water hyacinth root are good option for the decontamination of $\mathrm{Cd}$ in aqueous medium. But in line with the trend of absorption $\mathrm{Cd}$ is believed to be the last to be absorbed, particularly which due its size and smaller ionic radius (Table 4).

Table 4. Adsorption Trends/properties of the Metals in View.

\begin{tabular}{|c|c|c|c|c|c|}
\hline Elements & Electro Negativity & Oxidation states & No of electrons & Ionic radius (clement Enrico, 1967) & Size rating \\
\hline $\mathrm{Cd}$ & 1.69 & $2+$ & 48 & 155 & 3 \\
\hline $\mathrm{Fe}$ & 1.83 & $0,2+, 3+$ & 26 & 156 & 2 \\
\hline $\mathrm{Cr}$ & 1.66 & $3+, 6+$ & 24 & 166 & 1 \\
\hline
\end{tabular}

Algae recorded $\mathrm{Fe}$ concentration of $80.80 \mathrm{mg} / \mathrm{kg}$ at 5 $\mathrm{mg} / \mathrm{l}$ of the multi component metal solution, while water hyacinth shoot recorded $\mathrm{Fe}$ value of $235.32 \mathrm{mg} / \mathrm{kg}$. However, water lettuce root showed the highest accumulation $(538.59 \mathrm{mg} / \mathrm{kg})$. The difference in the accumulation of the metal between the different plants may results from the differences in the physiological activities of the plants (such as photosynthesis).

The presence of significant amount of $\mathrm{Fe}$ in the control sample of Algae and water hyacinth root is due to the fact that $\mathrm{Fe}$ is an essential micro nutrient to the plants, it's required for plant growth, essential for the chlorophyll synthesis, makes up about $75 \%$ of the content of chloroplast in leaf cell, and also participates in the electron transport in the process of reduction via cytochromes and ferredoxin [18, 31-33]. The presence of $\mathrm{Fe}$ in the control sample may also results from the presence of ferritin, or that the plant has already accumulated high amount Fe [34].

Considering the bioconcentration factor of $\mathrm{Fe}$ in water lettuce i.e the plant with the highest accumulation value (Table 2), the values are very low at all concentration. This is a very good advantage from point view of phytoremediation, since a plant is classified as a very good phytoremediator when it has a high accumulation value and low bioconcentration factor, i.e when a plant concentrated more of the metal in the root without transferring it to the aerial part of the plant (as observed in the case of water lettuce above). Studies done by Vardanyan and Ingole, (2006) corroborates similar trend [3].

Chromium concentration in the plants under investigation recorded highest value in water hyacinth root with 1661.94 $\mathrm{mg} / \mathrm{kg}$, followed by algae with $671.28 \mathrm{mg} / \mathrm{kg}$ and finally water lettuce root with $28.84 \mathrm{mg} / \mathrm{kg}$ (Table 1), judging from the result above, water hyacinth have the ability to accumulate $\mathrm{Cr}$ more compared to other plants under investigation. Similar results were reported by Yasar et al., (2013), but the results herein are higher [30]. The results for $\mathrm{Cr}$ in Table 1 showed that water hyacinth root is the best of the three plants, serving as a good candidate for decontamination of chromium in aqueous medium.

Additionally, the presence of $\mathrm{Cr}$ in the control sample of Algae, water hyacinth root and shoot (Figure 3), could possibly come from pollution in the water ways, since the plant's base is in a river that flows around inhabitation of people. The low concentration of $\mathrm{Cr}$ that was recorded in the shoot of water hyacinth is as a result of poor transport mechanism from the root [34].

Of the three metals $(\mathrm{Cd}, \mathrm{Fe}$ and $\mathrm{Cr}$ ) under investigation, $\mathrm{Cr}$ has the highest accumulation in the following decreasing order by W.H root $5 \mathrm{ppm}>\mathrm{W} . \mathrm{H}$ root $3 \mathrm{ppm}>$ Algae $5 \mathrm{ppm}$, followed by $\mathrm{Fe}$ in W.L $5 \mathrm{ppm}>3 \mathrm{ppm}>1 \mathrm{ppm}$ and finally cadmium with the least accumulation in W.H root $5 \mathrm{ppm}>$ Algae $5 \mathrm{ppm}>\mathrm{W} . \mathrm{H}$ root $3 \mathrm{ppm}$ (W.H = water hyacinth, $\mathrm{W} . \mathrm{L}=$ water lettuce). In summary the total accumulating metals decreased in the following order $\mathrm{Cr}>\mathrm{Fe}>\mathrm{Cd}$.

The good absorption level for the metals by the three plants portrayed their good remediating potential. Additionally, their ability to accumulate more than one metal at a time is surplus to their remediation potential. Water hyacinth was able to accumulate most of the metals thus the best of the three plants under investigation followed by water lettuce and algae.

\section{Conclusion}

In this study, algae, water hyacinth and water lettuce were used in order to assess their phytoremediative properties. The plants have proved to be good accumulators for $\mathrm{Cr}, \mathrm{Fe}$ and $\mathrm{Cd}$, serving as good biological filters of waste waters, which gives a good alternative for heavy metals removal from waste waters mainly due its sustainability.

Of the three plants used, water hyacinth and water lettuce are the highest accumulators which could be attributed to their large body mass and their rooted nature. This property, has favoured their rhizopheric activity, and enhances the metal uptake. On the other hand, Algae has also shown a good potential, and accumulated a considerate amount of the metals under study. The ability of the plants to accumulate more than one metal, has proven further their phytoremediative properties towards decontaminating waste waters.

\section{References}

[1] Banach, A. M., Banach, K., and Stepniewska, Z., (2012) "Phytoremediation as a Promising Technology for Water and Soil Purification; Azolla Carolliana Wild. as a case study. Acta Agro Physica 19 (2), 241-252. 
[2] Thayaparan M., Iqbal S. S., Chatburanga P. K. D., Iqbal M. C. $\mathrm{M}$ (2013) "Rhizofiltration of $\mathrm{Pb}$ by Azollapinnata" International journal of environmental sciences, Vol. 3, No 6.

[3] Vardanyan, L. G., and Ingole, B. S., (2006) "Studies on Heavy Metal Accumulation in Aquatic Macrophytes from Sevan (Armenia) and Carambolim (India) lake systems". Environment. International 32, 208-218.

[4] Singh, D., Archana, T., and Richa G., (2012). "Phytoremediation of Lead from Waste Water Using Aquatic Plants" Journal of Agricultural Technology. Vol. 8 (1): 1-11. ISSN 1686-9141.

[5] Prajapati, S. K., Meravi, N., and Singh, S., (2012) "Phytoremediation of Chromium and Cobalt using Pistia Stratiotes: A Sustainable Approach" proceedings of the international Academy of Ecology and Environmental Sciences, 2 (2), 136-138.

[6] Victor, K. K., Seka, Y., Nobert, K. K., Sinogo, T. A. and Celestin, A. B. (2016): Phytoremediation of Wastewater Toxicity Using Water Hycinth (Eichorniacrassipes) and Waterlettuce (Pistiastratiotes), International Journal of Phytoremediation 18 (10): 949-945.

[7] Zohaib, A., Fariha, A., Shafaqat, A., Elahi, Z. I., Muhammad, R. and Ahsan, R. M. (2019): Phytoremediation of Land fill Leachate Waste Contaminants Through Floating Bed Technique Using Water Hycinth and Water lettuce, International Journal of Phytoremediation 21 (13): 1356-1367.

[8] Chmielewska, E., and Jad, M., (2001)"Bioaccumulation of Heavy Metals by Green Algae CladophoraGlomerata in a Refinery Sewage Lagoon, CROATIA. CHEMICA ACTA CCACCA 74 (1) 135-145.

[9] Benchraka, C., (2014) "The Role of Algae in Heavy Metals Removal from Mining Wastewater", Thesis Tempere University of Applied Science.

[10] Giovanni, C., Stefania, C., (2012). "Selective Biosorption and Recovery of Ruthenium from Industrial Effluents with Rhodopseudomonas Palustris Strain" Applied Microbiology Biotechnology, 95, 381-387.

[11] Worku, A., Sahu, O., (2014). "Reduction of Heavy Metal and Hardness from Ground Water by algae" Journal of Applied and Environmental Microbiology, Vol. 2, No. 3, 86-89.

[12] John, G. R., (2007) "Zinc and Chromium Removal Mechanisms from Industrial Waste Water by using Water Hyacinth, Eicchornia Crasssipes" a Thesis Submitted to National University of Rwanda, memoir online.

[13] Ebel, M., Evangelou, M. W. H., Schaeffer, A., (2007). "Cyanide Phytoremediation by Water Hyacinths (Eichhornia Crassipes)". Chemosphere 66, 816-823.

[14] Fang, Y. Y., Yang, X. E., Chang, H. Q., Pu, P. M., Ding, X. F., Rengel, Z., (2007). "Phytoremediation of Nitrogen-Polluted Water using Water Hyacinth”. Journal Plant Nutrient. 30, 1753-1765.

[15] Alvarado, S., Guédez, M., Lué-Merú, M. P., Nelson, G., Alvaro, A., Jesús, A. C., Gyula, Z., (2008.) “Arsenic Removal from Waters by Bioremediation with the Aquatic Plants Water Hyacinth (EichhorniaCrassipes) and Lesser Duckweed (Lemna minor)". Bioresour. Technol. 99, 8436-8440.

[16] Giraldo, E., Garzon, A., (2002). "The Potential for Water Hyacinth to Improve the Quality of Bagota River Water in the
Muna Reservoir; Comparison with the Performance of Waste Stabilisation Ponds. Water Science Technology 45 (1), 103 - 110.

[17] Swain, G., Adhikari, S., Moharty, P., (2014). "Phytoremediation of Copper and Cadmium from Water using water Hyacinth (Eicchorniacrassipes)" International Journal of Agricultural science and Technology, Vol 2.

[18] Narain, S., Ojha, C. S. P., Mishra, S. K., Chambe, V. C., Sharma, P. K., (2011). "Cd and Cr removal by Aquatic Plant. International journal of environmental sciences. Vol 1, No 6.

[19] Odjegba, V. J., Fasidi, I. O., (2004). “Accumulation of Trace Elements by PistiaStratiotes: Implications for phytoremediation". Ecotoxicology 13, 637-646.

[20] Skinner, K., Wright, N., Porter-Goff, E., (2007). "Mercury Uptake and Accumulation by Four Species of Aquatic Plants". Environmental Pollution. 145, 234-237.

[21] Tewari, A., Singh, R.., Singh, N. K., Rai, U. N., (2008). "Amelioration of Municipal Sludge by Pistiastratiotes L.: Role of antioxidant enzymes in detoxification of metals". Bioresource Technology. 99, 8715-8721.

[22] Zimmels, Y., Kirzhner, F., Malkovskkaja, A., (2006). "Application of Eicchornia Crassipes and Pistia Stratiotes for Treatment of Urban and Sewage in Israel". Journal Environmental Management 81, 420-428.

[23] Espinosa, R. S., (2001). "Lead Uptake and Growth Responses in Pistia Stratiotes Linn. (Quiapo)". The Manila Journal of science, Vol. 4. No. 1.

[24] Thilakar, R., Pillai, P., (2012) "Phytoaccumulation of Chromium and copper by Pistiastratiotes $L$. and Salvinianatans (L)" Journal of Natural Product and Plant resources. $725-730$.

[25] Ugya, A. Y, Tijjani, S. I and Salisu, M. T., (2015). "The use of Pistia Stratiotes to Remove some Heavy Metals from Romi Stream: A case of Kaduna Refinery and petrochemical company polluted Stream", IOSR Journal of Environmental Science, Toxicology and Food Technology (IOSR-JESTFT) Vol. 9 Issue 1 Ver. II Pp 48-51.

[26] Irfan. S., (2015). "Phytoremediation of Heavy Metals using MacrophyteCulture". Journal of International Scientific Publications, Ecology \& Safety, Vol. 9. ISSN 1314-7234.

[27] Miroslav, R. and Vladimir, N. B., (1999). "Practical Environmental Analysis". Published by The Royal Society of Chemistry, Thomas Graham House, Science Park. Milton Road Cambridge.

[28] Chakroun, H. K., Souissi, F., Bouchardon, J., Souissi, R., Moutte, J., Faure, O., Remon, E., and Abdeljaoued, S., (2010)"Transfer and Accumulation of Lead, Zinc, Cadmium and Copper in Plants Growing in Abandoned Mining-District Area" African Journal of Environmental Science and Technology. Vol. 4 (10) Pp 651-659. ISSN 1991-637X.

[29] Harrison, R. M., (1999). "Understanding Our Environment; An Introduction to Environmental Chemistry and Pollution", $3^{\text {rd }}$ edition, published by Royal Society of Chemistry.

[30] Yasar, A., Khan, M., Tabinda, A. B., Hayyat, M. U., and Zaheer, A., (2013) "Percentage Uptake of Heavy Metals of Different Macrophytes in Stagnant and Flowing Textile Effluent" The Journal of Animal and Plant Sciences, 23 (6), $1709-1713$, ISSN: $1018-7018$. 
[31] Marschner, H., (1995). "Mineral Nutrition of Higher Plants". London, Academic Press, 889p.

[32] Mengel, K., and Kirkby, E., (2001)"Principles of Plant Nutrition". $5^{\text {th }}$ Edition Dordrecht/Boston/London Kluwer Academic Publishers. 849p.

[33] Malavolta, E., (2006), “ NutriçãoMineral de Plantas”. São Paulo, Agronômica Ceres. 631p.
[34] Miretzky, P., Saralegui, A., and Cirelli, A. F., (2006). "Aquatic Macrophytes Potential for the Simultaneous Removal of Heavy Metals (Buenos Aires Argentina)", Chemosphere, 57 (8), Pp 997-1005.

[35] Liao, S. W., and Chang, W. L., (2004). "Heavy Metal Phytoremediation by Water Hyacinth at Constructed Wetlands in Taiwan” Journal Aquatic Plant Management, 42: 60-68. 